\title{
Job Burnout and Job Engagement Dimensions Among Hotel Employees in Sarawak: What Is the Relationship?
}

\author{
Mark Kasa ${ }^{1}$, Azizan bin Yatim² ${ }^{2}$ Francesca Enchang ${ }^{3}$, Danial Yong ${ }^{1} \&$ Nursyafiqah Ramli $^{1}$ \\ ${ }^{1}$ Faculty of Hospitality \& Tourism Management, UCSI University Malaysia, Malaysia \\ ${ }^{2}$ Centre for Pre-U Studies, UCSI University Malaysia, Malaysia \\ ${ }^{3}$ Faculty of Business \& Management, UCSI University Malaysia, Malaysia \\ Correspondence: Mark Kasa, Faculty of Hospitality \& Tourism Management, UCSI University Malaysia, Malaysia.
}

Received: July 19, 2020

doi:10.5430/rwe.v11n6p207
Accepted: October 15, 2020

Online Published: December 10, 2020

URL: https://doi.org/10.5430/rwe.v11n6p207

\begin{abstract}
Hotel employees are constantly working in an increasingly stressful work environment. As hotel employees working in a demanding working environment, they may eventually face job burnout dimensions (emotional exhaustion, cynicism, reduced professional efficacy) due to the day-to-day operations which lead to burnout phenomenon. Despite the limited study investigating burnout dimensions particularly revealing the research finding in the non-western context which may have adverse effects on their relationship with their job engagement phenomena. The study aims to explore the correlation between job burnout dimensions and job engagement dimensions among hotel employees in Sarawak, Malaysia. In more specified, each of the burnout dimensions will be tested on its significant relationship with job engagement dimensions (vigour, dedication, absorption). Cross-sectional research design with a total of 201 valid responses were obtained which involved descriptive and inferential statistic with high reliability scoring while exploratory factor analysis values met the benchmark. This study can be utilized by the hotel industry to develop effective strategies to minimize job burnout of each dimension while enhancing job engagement among the hotel employees in Sarawak.
\end{abstract}

Keywords: job burnout, job engagement, hotel employee, Sarawak

\section{Introduction}

Hotel employees are responsible to maintain excellent work performance standard as services to the customer is very important. Job burnout and job engagement of hotel employee had grabbed the attention of researchers in the past few decades as it is one of the major corporate issues (Kasa et al., 2018). Job burnout is a psychological condition in which a person experiences exhaustion caused by emotional turmoil, having a sense of lacking personal accomplishment, and detaching themselves from reality (Talachi and Gorji, 2013). Since work performed by hotels demands full attention and caution to ensure the excellent services provided to the customers, few factors may lead the hotel employees to feel exhausted on their works. In general, employees often experience different levels of job-related distress which will ultimately expose them to exhaustion, disengagement, and health-related issues (Schaufelli \& Greenglass, 2001), especially in the field of hotel industry due to the increase of competition in hospitality sector based on the increasing number of foreigner employee.

The association of job burnout dimensions and job engagement was studied mostly in Western societies. The degree of work commitment is the degree of individual psychological acceptance of the work; or the importance of the mind that is focused on doing the job individually (Sonnentag, 2003). Warr and Inceoglu (2012) stated that job engagement is when an individual agrees with the value of a job has to offer, leading to the individual's willingness to work on it. Thus, the positive impact deriving from job engagement is highly valued by any company. In the corporate arena, job engagement helps to reduce the issue of absenteeism (Scott \& Mcclellan, 1990), decrease the rate of turnover (Xanthopoulou et al., 2009), promote the increase in performance (Brown \& Leigh, 1996), boost in-role performance and bolster organizational citizenship behaviours (Diefendorff et al., 2002). As revealed by various past research, workers is more likely to improve their individual effort if they are engaging in their job (Brown \& Leigh, 1996), more likely to experience job satisfaction, increase in the level of job accuracy, and is more complete in terms of communicating with others (Orpen, 1997). Nevertheless, past research mainly focused only on 
the positive spectrum on what job engagement offers and little emphasis was placed on the research of the negative spectrum. This study will assume that the right level of job engagement serves to improve job performance - positive impact, however extreme job engagement can lead to the experience of job burnout - negative impact.

Conservation of Resources (COR) theory is being applied in this study. The theory proposed that resources of self-esteem, social support, security, time and money, are constantly being seek out by individuals for the purposes of obtaining and maintaining and that the loss of these resources will cause the experience of stress (Hobfoll, 1989). In short, an employee tends to be stressful due to the worried of loss of resources. This theory is applicable for this study as the job burnout dimensions of hotel employee is distress by the standard of services provided. Therefore, the purpose of this study is to identify the relationship between job burnout dimensions and job engagement among hotel employee in Sarawak, contributing to the knowledge of burnout dimensions of emotional exhaustion, cynicism, and reduced professional efficacy, and engagement in term of vigour, dedication and absorption, among hotel employees.

\section{Literature Review and Hypothesis}

Burnout can be differentiated into three dimensions-Emotional exhaustion, cynicism, and reduced professional efficacy (Maslach \& Jackson, 1981) - which can be found being experienced by employees of various occupation (Bakker et al., 2003; Schaufeli \& Enzmann, 1998). Based on the explanation given by Demerout er al., (2000), the feeling of exhaustion refers to the feeling of over-extended due to work emotional demand. In this study, it is referring to the hotel employees' feeling of exhaustion due to being overloaded with work. Meanwhile, cynicism is known to be 'the attitude of scornful or jaded negativity' that comes out with a sense of deeply embed negative view or distrust towards the world (Johnson, 2005)'. Cynicism in this study focuses on the attitude of hotel employees who are distrusting or having doubts among their peer, mostly referring to an employee in upper management who had the power among the others. Reduced professional efficacy is known as the inclination to examine other's work in a negative way (Maslach \& Jackson, 1981); referring to the hotel employee with low confident level who did not trust in themselves in organizing a task.

Job engagement is the result derived from positive psychological processes (Chen and Chen, 2010) which had been characterized into vigour, dedication and absorption (Schaufeli et al., 2002). The characteristic of vigour can be defined as 'high levels of energy and mental resilience while working, the willingness to invest effort in one's work and persistence even in the face of difficulties' (Schaufeli \& Salanova, 2007); dedication is known as the effort of being strongly participated in one's work and experiencing self-significance, passionate, inspiring, self-respect and competitiveness; lastly absorption is known as the positive feeling of a person who involved in the work provided.

The concept of job burnout and job engagement was being studied throughout the decades as the practical measure of psychological behaviour of employees in the service-oriented industry (Chen and Chen, 2010). Past studies have revealed the existence of a relationship between a high level of work engagement and job performance, increase in organizational commitment, reduction in absence rate and low turnover level (Salanova, 2005; Bakker, 2006; Schaufeli \& Salanova, 2007). The job engagement by the opposite pattern of scores on the three burnout dimensions had been studied once by Maslach and Leiter in the year 1997; however, Diener (1999) argued that job burnout and work engagement are two different independent variables. The current study intends to re-examine the correlation between job burnout and job engagement to support the previous researcher's state of mind.

This study adheres to the core concept of having job burnout as independent variable and job engagement dimensions as a dependent variable to create a model consisting of three hypotheses as shown in Figure 1.

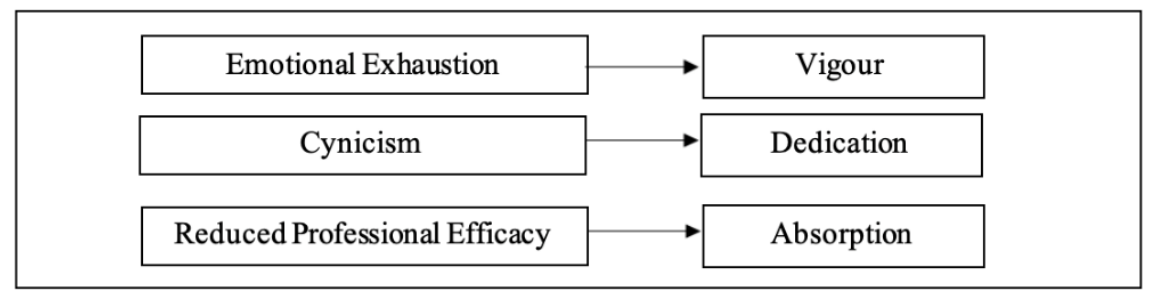

Figure 1. The research proposed model

Hypothesis 1: There is a significant relationship between emotional exhaustion and vigour.

Hypothesis 2: There is a significant relationship between cynicism and dedication. 
Hypothesis 3: There is a significant relationship between reduced professional efficacy and absorption.

\section{Methodology}

The quantitative research method was applied to this study, with self-administered survey questionnaires were employed through non-probability sampling method, purposive method. A total of 201 questionnaires were distributed to respondents working as hotel employees in Sarawak, Malaysia; which had exceeded the minimum sampling (138 respondents) needed as per calculated using Raosoft sample size calculator (margin error 5\%, confident level 95\%). There are no major issues found through observation on normality, outliers, validity and reliability. The constructed item had a factor loading from 0.423 to 0.970 which had exceeded 0.40 (Hair et al., 1998), Kaiser-Meyer-Olkin (KMO) value had exceeded 0.70 with a range of 0.715 to 0.856 and Barlett Sphericity Test had shown the p-value of 0.000 which is below 0.50 . Therefore, it indicated that all correlation matrixes are free of similarity from an identity of the matrix (Hair, 1998). Lastly, as per Table 1, research instruments were all adopted from past study and had exceeded the Cronbach Alpha value of 0.70, which shows positive reliability (Nunnally, 1978).

Table 1. The research instrument

\begin{tabular}{lcccccc}
\hline Measure & Items & Sources & $\begin{array}{c}\text { Factor } \\
\text { Loading } \\
(>.40)\end{array}$ & $\begin{array}{c}\text { KMO } \\
(>.70)\end{array}$ & $\begin{array}{c}\text { Bartlett's Test } \\
\text { of Sphericity } \\
(>.70)\end{array}$ & $\begin{array}{c}\text { Cronbac } \\
\text { h Alpha } \\
(>.70)\end{array}$ \\
\hline $\begin{array}{c}\text { Professional } \\
\text { Efficacy }\end{array}$ & 6 & Maslach, \& Jackson, (1981) & $.423-.940$ & .775 & $\begin{array}{l}466.619 \\
\mathrm{P}=0.000\end{array}$ & 0.841 \\
\hline Cynicism & 4 & Maslach \& Jackson, (1981) & $.478-.924$ & .762 & $\begin{array}{c}507.624 \\
\mathrm{P}=0.000\end{array}$ & 0.890 \\
\hline $\begin{array}{c}\text { Emotional } \\
\text { Exhaustion }\end{array}$ & 5 & Maslach \& Jackson, (1981) & $.477-.886$ & .819 & $\begin{array}{l}768.003 \\
\mathrm{P}=0.000\end{array}$ & 0.918 \\
\hline \multicolumn{1}{c}{ Vigor } & 6 & Schaufeli \& Bakker (2003) & $.468-.901$ & .856 & $\begin{array}{l}491.558 \\
\mathrm{P}=0.000\end{array}$ & 0.876 \\
\hline Dedication & 5 & Schaufeli \& Bakker (2003) & $.742-.970$ & .837 & $\begin{array}{l}341.343 \\
\mathrm{P}=0.000\end{array}$ & 0.820 \\
\hline Absorption & 6 & Schaufeli \& Bakker (2003) & $.557-.938$ & .776 & $\begin{array}{l}210.556 \\
\mathrm{P}=0.000\end{array}$ & 0.781 \\
\hline
\end{tabular}

\section{Results and Findings}

\subsection{Respondents' Demographic}

There was a total of 201 respondents, consisting of $57 \%$ of female (116 respondents) and $42 \%$ of male ( 85 respondent). Majority of the respondents were age less than 30 years old (70\%), 31-39 years old as second (23\%), and lastly 40-49 years old as least (7\%). As per race, the majority is Chinese (47\%), followed by Iban (21\%), Bidayuh (18\%) and Malay (14\%); while 69\% of them were single and $31 \%$ was married. There were $69 \%$ working in the non-managerial sector, and $31 \%$ working in the managerial sector with the longest range of 5 years and above (27\%), followed by 1 to 5 years (40\%) and less than a year (33\%).

\subsection{Hypotheses Testing}

To ensure reliability and validity standards were met, explanatory factor analysis and Cronbach alpha were applied in this study. As shown in Table 2, the result of Pearson Correlation analysis had shown the inferential statistic of all variables, which between absorption and professional efficacy, it shows a result of $r=.476$ at $p=.000$; between vigour and emotional exhaustion, it shows a result of $\mathrm{r}=.553$ at $\mathrm{p}=.000$; and between dedication and cynicism, the result is $r=.535$ at $\mathrm{p}=.000$ ( $\mathrm{p}<.01)$ significant level at 2 tailed test). The statistical result had accepted and supported all hypothesis proposed - there is a significant relationship 1) between absorption and professional efficacy, 2) between vigour and emotional exhaustion, and 3) between dedication and cynicism. 
Table 2. Inferential Statistics-Person's Correlation Analysis

\begin{tabular}{lcccccc}
\hline \multicolumn{1}{c}{ Variables } & $\begin{array}{c}\text { Professional } \\
\text { Efficacy }\end{array}$ & Cynicism & $\begin{array}{c}\text { Emotional } \\
\text { Exhaustion }\end{array}$ & Vigour & Dedication & Absorption \\
\hline Professional & 1 & & & & & \\
Efficacy & & & & & & \\
Cynicism & $.592^{* *}$ & 1 & & & & \\
Emotional & .000 & $.623^{* *}$ & 1 & & & \\
Exhaustion & & & & & & \\
Vigour & $.464^{* *}$ & $.498^{* *}$ & $.553^{* *}$ & 1 & & \\
Dedication & $.496^{* *}$ & $.535^{* *}$ & .031 & $.504^{* *}$ & 1 & $.638^{* *}$ \\
Absorption & $.476^{* *}$ & .003 & $.705^{* *}$ & $.705^{* *}$ &. & \\
\hline
\end{tabular}

\section{Discussion}

Hypothesis $1\left(\mathrm{H}_{1}\right)$ suggested that emotional exhaustion is significantly related with vigour. Emotional exhaustion is referred to as the state where the stress created from work causes an individual to be emotionally worn out (Maslach \& Jackson, 1981; Cordes \& Dougherty, 1993). Meanwhile, vigour refers to the presence of energy with the absence of exhaustion and fatigue (MacArthur, 1997). The correlation between emotional exhaustion and vigour can be portrayed mainly from two perspectives - bipolar perspective (Maslach \& Leiter, 1997) and bivariate perspective (Shirom et al., 2013). Bipolar perspective describes both emotional exhaustion and vigour items measure one fundamental bipolar dimension. Therefore, they can be measured on an underlying bipolar dimension identified as "energy" (Gonzales, 2006). Energy is one of the vital elements which can ensure the effectiveness and efficiency of the work performance (Dutton, 2003). It can be assumed that an individual with high emotional exhaustion will feel less energized, lack of concentration at work and thereby decreasing the individual's vigour (Mulki et al., 2006). In the context of a hotel setting, the bipolar perspective claims that hotel employees are unable to experience both emotional exhaustion and vigour simultaneously. However, the bivariate perspective suggests that emotional exhaustion and vigour do not represent two distinctive extremes of a similar dimension but are indirectly related (Shirom et al., 2013). Thus, the experience of emotional exhaustion and vigour might occur simultaneously as both variables are two different and separable experiences. In sum, at the individual level, emotional exhaustion and vigour are two distinctive experiences and therefore can co-exist in a person and generate different patterns of exhaustion-vigour.

Meanwhile, hypothesis $2\left(\mathrm{H}_{2}\right)$ indicated that cynicism is related to dedication. Cynicism refers to a negative and insensitive thought or attitude towards a job. On the other hand, dedication shows the opposite trends which refers to a positive and fulfilling thought and attitude in mind towards a job (Maslach et al., 2001). Dedication is included vigorously in an individual's experience of enthusiasm, fulfilment, challenge, seriousness, and creativity (Schaufeli et al., 2002). Dedication is perceived as the total opposite of cynicism (Maslach \& Leiter, 1997; Schaufeli et al., 2002). As cynicism seems to grow with the reaction to exhaustion and professional effectiveness grows independently (Leiter, 1993). Thus, when an individual is being cynical, he/she is unlikely to be dedicated to a job. In short, there is a significant relationship between cynicism and dedication since cynicism shows a negative attitude towards a job, while dedication shows the positive attitude towards a job (Maslach et al., 2001; Schaufeli et al., 2002). Hence, cynicism and dedication are two different incidents that occur separately in an individual which means an individual can't have these two traits at the same time.

Hypothesis $3\left(\mathrm{H}_{3}\right)$ proposed that professional efficacy and absorption is significantly related. Reduced professional efficacy is defined as a sense of decrease in professional accomplishment and competence (Greenglass et al, 2003). Besides that, absorption can be described as a pleasant state of immersion in one's work (Taris et al., 2017). Past studies claim that individuals with elevated levels of professional self-efficacy are linked to fewer challenging demands which subsequently linked to a higher level of engagement which encompasses the three dimensions which are vigour, commitment and absorption (Salanova et al., 2005). The studies indicate that absorption and efficacy may be considered under the concept of engagement (Schaufeli \& Greenglass, 2001). Thus, job engagement being an intrinsic work-driven motivation can be influence by people's low levels of self-efficacy. Furthermore, there is a positive relationship between individuals with low levels of professional self-efficacy and the experience of a higher level of hindrance demands and having their relationship affected by adverse experiences such as burnout (Ventura \& Salanova, 2014), This also entails a decrease in energy levels and commitment in the face of competition and a lack of appreciation of jobs (Lloren et al., 2005). 


\section{Conclusion and Implications}

This study aims to determine the relationship between job burnout dimensions and job engagement among hotel employees in Sarawak. Ample of studies have been conducted on the fact to achieve a high level of job performance, a high level of job engagement is required. However, being immersed in high levels of job engagement contain the potency leading to job burnout. When an employee put excessive effort into their work, it can constitute the experience of job burnout. It is recommended for organisation to put more emphasis on the phenomenon of high-level employees' job burnout as if there is employee burnout, an employee will lack the motivation to work. It is also recommended for the hotel industry to implement policies to provide a positive workplace environment for the employee in term of social, mental and physical wellbeing. These recommendations may help in preventing employees from experiencing burnout that leads to disengagement.

\section{References}

Bakker, A. B., Demerouti, E., de Boer, E., \& Schaufeli, W. B. (2003). Job demands and job resources as predictors of absence duration and frequency. Journal of Vocational Behavior, 62, 341-356

Bakker, A. B., Emmerik, H. V., \& Euwema, M. C. (2006). Crossover of Burnout and Engagement in Work Teams. Work and Occupations, 23(4), 464-489.

Brown, S. P., \& Leigh, T. W. (1996). A new look at psychological climate and its relationship to job involvement, effort, and performance. Journal of Applied Psychology, 81(4), 358-368.

Chen, C-F., \& Chen, S-C. (2010). Burnout and Work Engagement Among Taiwanese Flight Attendants: The Application of Job Demands-Resources Model.

Cordes, \& Dougherty. (1993). Emotional exhaustion can be known as the situation while stress created from the work-life caused the emotionally worn out of an individual's feeling. Academy of Management Review, 18, 621-656.

Demerouti E., Bakker, A. B., Nachreiner, F., \& Schaufeli, W. B. (2000). A model of burnout and life satisfaction among nurses. Journal of Advanced Nursing, 32, 454-464.

Diefendorff, J. M., Brown, D. J., Kamin, A. M., \& Lord, R. G. (2002). Examining the roles of job involvement and work centrality in predicting organizational citizenship behaviors and job performance. Journal of Organizational Behavior, 23(1), 93-108.

Diener, E. (1999). Introduction to the special section on the structure of emotion. Journal of Personality and Social Psychology, 76, 803-804.

Dutton, J. (2003). Energize your workplace: How to build and sustain high-quality connections at work. San Francisco: Jossey-Bass Publishers.

Gonzalez-Roma, V., Schaufeli, W. B., \& Bakker, A. B. (2006). Burnout and work engagement: Independent factors or opposite poles?. Journal of Vocational Behavior, 165-174.

Greenglass, E. R., Burke, R. J., \& Moore, K. A. (2003). Reactions to increased workload: Effects on professional efficacy of nurses. Applied Psychology: An International Reviw, 52(4), 580-597.

Hair, J. F. J., Anderson, R. E., Tatham, R. L., \& Black, W. C. (1998). Multivariate Data Analysis (5th ed.). New Jersey: Prentice Hall, Upper Saddle River.

Hobfoll, S. E. (1989). Conservation of resources: A new attempt at conceptualizing Stress. American Psychologist, 44, 513-524.

Johnson, B. (2005). Overcoming "doom and gloom": Empowering students in courses on social problems, injustice and inequality. Teaching Sociology, 33(1), 44-58.

Kasa, M., Hassan, Z., \& Yatim, A. (2018). Does Flow Experience Really Matter Among Hotel Employees in Sarawak?. International Journal of Engineering and Technology, 7(3.30), 11-14. https://doi.org/10.14419/ijet.v7i3.30.18145

Leiter, M. P. (1993). Burnout as a developmental process. Consideration of models. In W. B. Schaufeli, C. Maslach, \& T. Marek (Eds.), Professional burnout: Recent development in theory and research (pp. 237-250).

Llorens, S., Garc'1a, M., \& Salanova, M. (2005). Burnout as a consequence of efficacy crisis: A longitudinal study in secondary school teachers, 21, 55-70.

MacArthur. (1997). Research Network on SES \& Health. Retrieved from https://macses.ucsf.edu/research/psychosocial/vitality.php 
Maslach, C., \& Jackson, S. E. (1981). The measurement of experienced burnout. Journal of Occupational Behaviour, 2, 99-113. https://doi.org/10.1002/job.4030020205

Maslach, C., \& Leiter, M. P. (1997). The Truth About Burnout: How Organizations Cause Personal Stress and What to do About It. Jossey-Bass Publishers, San Francisco: CA.

Maslach, C., Schaufeli, W. B., \& Leiter, M. P. (2001). Job Burnout. Annual Review of Psychology, 397-442.

Mulki, P., Jaramillo, F., \& Locander, W. (2006). Emotional exhaustion and organizational deviance: Can the right job and a leader's style make a difference?. Journal of Business Research, 59(12), 1222-1230.

Nunnally, J. C. (1978). Psychometric Theory (2nd ed.). New York: McGraw-Hill

Orpen, C. (1997). The effects of formal mentoring on employee work motivation, organizational commitment and job performance. Learning Organization, 4(2), 53-60.

Salanova, M., Agut, S., \& Peiró, J. M. (2005). Linking organizational resources and Work engagement to employee performance and customer loyalty: The mediating role of service climate. Journal of Applied Psychology, 90, 1217-1227.

Salanova, M., Mart'inez, I. M., \& Llorens, S. (2005). Positive Organizational Psychology, 349-376.

Schaufeli, W. B., \& Enzmann, D. (1998). The burnout companion to study and practice: A critical analysis.

Schaufeli, W. B., \& Greenglass, E. R. (2001). Introduction to special issue on burnout and health. Psychol. Health, $16,501-510$.

Schaufeli, W. B., \& Salanova, M. (2007). Efficacy or inefficacy, that's the question: Burnout and engagement, and their relationships with efficacy beliefs. Anxiety, Coping \& Stress, 20, 177-196.

Schaufeli, W. B., Salanova, M., Gonzalez-Roma, V., \& Bakker, A. B. (2002). The measurement of engagement and burnout: A two sample confirmatory factor analytic approach. Journal of Happiness Studies, 71-92.

Schaufeli, W., \& Bakker, A. (2003). UWES Utrecht Work Engagement Scale. Preliminary Manual [Version 1, November 2003]. Utrecht University: Occupational Health Psychology Unit.

Scott, K. D., \& Mcclellan, E. L. (1990). Gender Differences in Absenteeism. Public Personnel Management, 19(2), 229-253.

Shirom, T., Melamed, B., \& Shapira. (2013). Burnout and vigor as predictors of the incidence of hyperlipidemia among healthy employees. Applied Psychology: Health and Well-Being, 5, 79-98.

Sonnentag, S. (2003). Recovery, work engagement, and proactive behavior: A new look at the interface between non-work and work. Journal of Applied Psychology, 88(3), 518-528.

Talachi, R. K., \& Gorji, M. B. (2013). Evaluating the Relationship between Job Burnout and Organizational Citizenship Behavior: A Study of Industry, Mine and Trade Organization Employees. Arabian Journal of Business and Management Review, 2(8), 50-61.

Taris, T. W., Ybema, J. F., \& Beek, I. Van. (2017). Burnout and engagement: Identical twins or just close relatives?. Burnout Research, 5(4), 3-11. https://doi.org/10.1016/j.burn.2017.05.002

Ventura, M., \& Salanova, M. (2014). Interdisciplinary and Applied Professional Self-Efficacy as a Predictor of Burnout and Engagement: The Role of Challenge and Hindrance Demands. Journal of Psychology, 37-41. https://doi.org/10.1080/00223980.2013.876380

Warr, P., \& Inceoglu, I. (2012). Job engagement, job satisfaction, and contrasting associations with person-job fit. Journal of Occupational Health Psychology, 17(2), 129-138.

Xanthopoulou, D., Bakker, A. B., Demerouti, E., \& Schaufeli, W. B. (2009). Reciprocal relationships between job resources, personal resources, and work engagement. Journal of Vocational Behavior, 74(3), 235-244.

\section{Copyrights}

Copyright for this article is retained by the author(s), with first publication rights granted to the journal.

This is an open-access article distributed under the terms and conditions of the Creative Commons Attribution license (http://creativecommons.org/licenses/by/4.0/). 